\title{
EFFECT OF ALBINO OPHIOSTOMA STRAINS ON EUCALYPTUS NITENS EXTRACTIVES
}

\author{
Juana Coloma ${ }^{1}$, Laura Reyes ${ }^{1}$, José Navarrete ${ }^{1}$, Julio Alarcón ${ }^{2}$, Lilian Delgado ${ }^{1}$, Renato Vera ${ }^{1}$, \\ Priscilla Ubilla ${ }^{1}$, Karen Vásquez $z^{3}$, José Becerra ${ }^{3}$
}

\begin{abstract}
Wood extractives promote pitch formation during pulp and paper manufacturing. To date, this problem has been controlled by extended storage of the chips and/or chemical additives. Biotreatment of the wood prior to pulping provides an alternative that not only decreases the negative impact of the extractives but may also improve the kraft pulping efficiency. This initiative seeks to verify the quantity and chemical composition of Eucalyptus nitens wood extractives following biotreatment with three albino fungi species (Ophiostoma floccosum, Ophiostoma piceae and Ophiostoma piliferum). Eucalyptus nitens wood chips were sprayed with spore suspensions of Ophiostoma piliferum, Ophiostoma piceae and Ophiostoma floccosum albino strains $\left(1 \times 10^{8}\right.$ spore concentration). After 7 and 21 days of fungal treatment, the extractive content was determined via Soxhlet extraction with an 80:20\% n-hexane:ethyl acetate solvent mixture. The Ophiostoma floccosum F1A94, Ophiostoma piliferum F2D8 and Ophiostoma piceae F2A68 strains proved to be most capable of bioreduction with reductions of $35.1 \%, 33.2 \%$ and $29.3 \%$, respectively. The chemical composition of the extract was analyzed via gas chromatography coupled with mass spectrometry, which demonstrated that most of the tested strains could reduce the $\beta$-sitosterol content.
\end{abstract}

Keywords: Albino fungi, Eucalyptus nitens, extractives, pitch, Ophiostoma, sitosterol.

\section{INTRODUCTION}

Wood extractives are organic compounds soluble in organic solvents and include polyphenols, terpenes, fats, waxes, complex polysaccharides and nitrogenized compounds, of which a fraction are saponified (fatty acids and sterol esters) and the rest (hydrocarbons, sterols, diverse alcohols and aldehydes) are unsaponifiable (Browning 1975, Rowe and Conner 1979, Fengel and Wegener 1984). The lipophilic extractives, which consist of fats, fatty acids, steryl esters, sterols, terpenoids and waxes (Fengel and Wegener 1989, Martínez-Ínigo et al. 2000, Gutiérrez et al. 2006), significantly contribute to pitch formation (Fengel and Wegener 1989, Burnes et al. 2000, Mouyal 2005, Sitholé et al. 2010). Pitch deposits result in low-quality pulp products, cause pulping equipment to wear out prematurely, can block and stop pulping operations, require costly chemical additives and can lead to economic losses (Fischer et al. 1996, Gutiérrez et al. 1999a, Soto 2001, Gutiérrez et al. 2001, Maltha et al. 2011, Pepijin et al. 2012). Pitch can be controlled both by the storage time of the pulpwood materials and by the addition of chemicals to the pulp suspension (Burnes et al. 2000, Soto 2001). Albino fungi strains from the Ophiostoma genus have been proposed as a biological treatment for wood deresination (Blanchette et al. 1992, Farrell et al. 2000, Martínez et al. 1995, Gutiérrez et al. 2001, del Río et al. 2001, Calero et al. 2004, Herrera et al. 2008).

\footnotetext{
Departamento de Ingeniería en Maderas, Universidad del Bío-Bío. Concepción, Chile. jucoloma@alumnos.ubiobio.cl, laurarn@ ubiobio.cl, jnavarre@ubiobio.cl,ldelgado@ubiobio.cl,rverah@ubiobio.cl.

2 Departamento de Ciencias Básicas, Universidad del Bío-Bío, Chillán, Chile. jualarcon@ubiobio.cl

${ }^{3}$ Departamento de Botánica, Universidad de Concepción, Concepción, Chile. jbecerra@udec.cl.

^Corresponding author : jnavarre@ubiobio.cl

Received: 23.06.2013 Accepted: 27.04. 2014
} 
Blanchette et al. (1992) and Fisher et al. (1994) inoculated Pinus taeda and Picea abies wood chips with the colorless piliferum (Cartapip 58) strain and found a 30\% decrease in the total resin content after two weeks of biological treatment. Similarly, Chen et al. (1994) examined the effect of Cartapip on Pinus contorta and poplar wood chips and found a 55\% and 70-80\% decrease, respectively, in their triglycerides after 2 weeks of fungal treatment. In another study, Burgos (2006) found that a mixed O. piliferum, O. piceae and $O$. floccosum spore suspension reduced the total extractive quantity of radiata pine woodchips by $40 \%$. Ophiostoma albino fungi have also been used to biologically treat Eucalyptus species. Gutiérrez et al. (1999b) found that $O$. valdivianum and $O$. piliferum strains could decrease the total extractives content by $70 \%$ after 40 days of fungal treatment. In another study, Calero et al. (2004) found that biotreatment with $O$. piceae could reduce sterol esters by $70 \%$.

Because biological treatments can significantly reduce the quantity of wood extractives, we conclude native Chilean albino Ophiostoma strains can be developed and their efficacy verified for reducing the extractive content in E. nitens wood, which is an increasingly important wood species for Chilean forestry.

Thus, the objectives of this study were a) to evaluate the effect of biological treatment on the extractive content of $E$. nitens wood, particularly its lipophilic fraction, using 30 albino strains of the Ophiostoma genus after 7 and 21 days of fungal treatment and b) to determine the effect of the three best albino strains, $O$. piliferum, $O$. piceae and $O$. floccosum, on the chemical composition of the E. nitens extractive lipid component over the same treatment period.

\section{MATERIALS AND METHODS}

Ten twelve-year-old Eucalyptus nitens (Deane and Maiden) Maiden trees were felled and three 2.4-m logs were cut from each tree. The logs were cut to 30,50 and $80 \%$ of their commercial height, which was defined as the total stem length measured from the bottom to the point at which the diameter was $12 \mathrm{~cm}$.

The 30 sampled logs were shipped to industrial facilities in CMPC Planta Santa Fe, Nacimiento (Chile). Logs from each tree were debarked and chipped, and the chips were classified and bagged at the industrial facility. The bags were identified and shipped to the Laboratorio de Biodeterioro at the Universidad del BíoBío. Chips from each tree were mixed in a $0.3-\mathrm{m}^{3}$ drum mixer for 3 minutes, and a representative sample was obtained based on the total weight. The sample chips were mixed again for 3 minutes, and $10 \%$ of the chips by weight were removed, bagged in sacks, placed in boxes and transported to the Compañía Chilena de Esterilización S.A., a facility located near Santiago, for sterilization using a 15-kGy dose of gamma irradiation.

\section{Inoculum preparation and chip biotreatment}

Isolated albino strains of Ophiostoma floccosum, O. piceae and O. piliferum were used for this study, and 10 isolates of each species were obtained from the Laboratorio de Biodeterioro culture collection at the Universidad del Bío-Bío (Table 1). Each albino isolate was cultured and aseptically transferred to several Petri dishes containing malt extract agar (MEA, 1.5\% Difco malt extract and 2.0\% agar) amended with antibiotics $(0,025 \%$ streptomycin and $0,025 \%$ chloramphenicol). The petri dishes were rinsed with sterile water after two weeks of culturing, and the obtained spore suspensions were poured into 250 -ml flasks containing $50 \mathrm{ml}$ of liquid media ( $15 \mathrm{~g}$ of malt extract per $1000 \mathrm{ml}$ of distilled water) (Held et al. 2003). The inoculum spore concentration, measured using a Neubauer hemocytometer, was approximately $1 \times 10^{5} \mathrm{spores} / \mathrm{ml}$. The cultures were centrifuged at $3,600 \mathrm{rpm}$ for 10 minutes after growing in a shaker at room temperature $\left(20-25^{\circ} \mathrm{C}\right)$ for 5 days. The supernatant was removed and a treatment solution was prepared for each isolate by resuspending the concentrate in distilled water to a final concentration of $1 \times 10^{8} \mathrm{spore} / \mathrm{ml}$. One-hundred twenty bags containing 2,7 kg E. nitens chips, 60 bags per treatment period and four per isolate, were inoculated using $10 \mathrm{ml}$ of the prepared spore suspension. The control bags, eight per treatment period, were sprayed with 10 $\mathrm{ml}$ of sterile water. 
Table 1. Strains selected for the Eucalyptus nitens chip biotreatment.

\begin{tabular}{|l|c|c|c|c|c|}
\hline $\mathrm{N}^{\mathrm{o}}$ & O. piceae strain code & $\mathrm{N}^{\mathrm{o}}$ & $\begin{array}{c}\text { O. floccosum } \\
\text { strain code }\end{array}$ & $\mathrm{N}^{\mathrm{o}}$ & $\begin{array}{c}\text { O. piliferum } \\
\text { strain code }\end{array}$ \\
\hline 1 & PcF2A68 & 11 & FlF1A94 & 21 & PIF2D8 \\
\hline 2 & PcF1A23 & 12 & FlF1A55 & 22 & PlF1A7 \\
\hline 3 & PcF1A32 & 13 & FlF1A9 & 23 & PIF2C60 \\
\hline 4 & PcF2A14 & 14 & FlF1A65 & 24 & PlF1A1 \\
\hline 5 & PcF2A70 & 15 & FlF1A2 & 25 & PlF2B82 \\
\hline 6 & PcF1A39 & 16 & FlF1A7 & 26 & PlF2C57 \\
\hline 7 & PcF2A9 & 17 & FlF1A8 & 27 & PIF2D6 \\
\hline 8 & PcF2A3 & 18 & FlF1A5 & 28 & PIF1A4 \\
\hline 9 & PcF2A35 & 19 & FlF1A18 & 29 & PlF2D88 \\
\hline 10 & PcF2A29 & 20 & FlF1A11 & 30 & PlF2B68 \\
\hline
\end{tabular}

\section{Determining the reduction in wood extractive}

After the desired fungal treatment time, the wood chips were placed on racks and dried in a 6- $\mathrm{m}^{3}$ gas kiln. The dry and wet bulb temperatures were 30 and $20^{\circ} \mathrm{C}$, respectively. The air velocity was adjusted to obtain a final moisture content of $12 \%$ after 24 hours. The dried wood chips from each treatment were ground in a Retsch SM 2000 mill according to the ASTM D1105-96 standard. The acceptable fractions, those between the 40 and 60 mesh sieves, were weighed, and $100 \mathrm{~g}$ was poured through paper filters.

The E. nitens wood samples were Soxhlet extracted for 4 hours using an n-hexane:ethyl acetate (80:20 $(\mathrm{v} / \mathrm{v}))$ solvent mixture. The extract was weighed using gravimetric analysis after evaporating the solvent mixture to dryness in a rotary evaporator.

\section{Determining the percent extractives, bioreduction factor and extractive chemical composition}

The extract was dried in a Buchi rotatory evaporator and weighed. A two-sample $t$-test was applied to each control and fungus-treated chip using a significance level of 5\% (Table 2). The extractive chemical compositions were analyzed via gas chromatography coupled with mass spectrometry (GC-MS) in the Laboratorio de Productos Naturales of the Facultad de Ciencias Naturales at the Universidad de Concepción.

The extract samples were seeded in a silica gel stationary phase using a mixture of n-hexane: ethyl acetate $(70: 30) \mathrm{v} / \mathrm{v}$ as the mobile phase. Sulfuric acid was sprayed at $30 \%$, and the silica gel plate was heated to observe the analytes. 
Table 2. Extractive content of $E$. nitens chips after 7 and 21 days of biotreatment.

\begin{tabular}{|c|c|c|c|c|c|c|c|}
\hline $\mathrm{N}^{\mathrm{o}}$ & Strain & $\begin{array}{l}\text { Extractives } \\
\text { Content } \\
7 \text { days }(\mathrm{g})\end{array}$ & $\begin{array}{c}\text { Standard } \\
\text { Deviation } \\
7 \text { days }\end{array}$ & $\begin{array}{c}\text { Factor } \\
\text { Bioreduction } \\
7 \text { days }\end{array}$ & $\begin{array}{l}\text { Extractives } \\
\text { Content } \\
21 \text { days }(\mathrm{g})\end{array}$ & $\begin{array}{c}\text { Standard } \\
\text { Deviation } \\
21 \text { days }\end{array}$ & $\begin{array}{c}\text { Factor } \\
\text { Bioreduction } \\
21 \text { days }\end{array}$ \\
\hline 1 & PcF2A68 & 0,22 & 0,02 & $16,62 *$ & 0,21 & 0,01 & $29,27 *$ \\
\hline 2 & PcF1A23 & 0,28 & 0,03 & $-5,69$ & 0,21 & 0,01 & $28,90 *$ \\
\hline 3 & PcF1A32 & 0,32 & 0,09 & $-21,41$ & 0,21 & 0,03 & $28,15^{*}$ \\
\hline 4 & PcF2A14 & 0,21 & 0,02 & $22,34 *$ & 0,21 & 0,02 & $27,95 *$ \\
\hline 5 & PcF2A70 & 0,46 & 0,66 & 7,71 & 0,22 & 0,01 & $27,31 *$ \\
\hline 6 & PcF1A39 & 0,22 & 0,01 & $16,57 *$ & 0,23 & 0,01 & $23,72 *$ \\
\hline 7 & PcF2A9 & 0,26 & 0,02 & 1,83 & 0,23 & 0,03 & $22,31 *$ \\
\hline 8 & PcF2A3 & 0,27 & 0,04 & $-1,08$ & 0,27 & 0,04 & 8,85 \\
\hline 9 & PcF2A35 & 0,31 & 0,04 & $-17,43$ & 0,27 & 0,05 & 8,2 \\
\hline 10 & PcF2A29 & 0,22 & 0,01 & $17,78^{*}$ & 0,31 & 0,03 & $-5,2$ \\
\hline 11 & FIF1A94 & 0,27 & 0,02 & $-2,23$ & 0,19 & 0,02 & $35,08 *$ \\
\hline 12 & F1F1A55 & 0,24 & 0,03 & 11,45 & 0,20 & 0,03 & $33,49^{*}$ \\
\hline 13 & FIF1A9 & 0,26 & 0,07 & 2,51 & 0,21 & 0,01 & $30,21 *$ \\
\hline 14 & FlF1A65 & 0,22 & 0,02 & 18,99 & 0,21 & 0,02 & $29,57 *$ \\
\hline 15 & FlF1A2 & 0,33 & 0,04 & $-23,41$ & 0,21 & 0,03 & $28,76^{*}$ \\
\hline 16 & FlF1A7 & 0,30 & 0,04 & $-11,42$ & 0,22 & 0,01 & $25,55^{*}$ \\
\hline 17 & FlF1A8 & 0,21 & 0,02 & 19,86 & 0,23 & 0,02 & $21,98^{*}$ \\
\hline 18 & FlF1A5 & 0,28 & 0,04 & $-5,28$ & 0,23 & 0,04 & $21,19^{*}$ \\
\hline 19 & FlF1A18 & 0,36 & 0,04 & $-34,24$ & 0,32 & 0,09 & $-7,26$ \\
\hline 20 & FlF1A11 & 0,23 & 0,07 & 13,1 & 0,44 & 0,58 & $-47,03$ \\
\hline 21 & PIF2D8 & 0,28 & 0,03 & $-5,06$ & 0,20 & 0,02 & $33,23 *$ \\
\hline 22 & PIF1A7 & 0,21 & 0,02 & 19,84 & 0,20 & 0,01 & $30,99 *$ \\
\hline 23 & PlF2C60 & 0,25 & 0,01 & 7,71 & 0,21 & 0,02 & $29,47 *$ \\
\hline 24 & PIF1A1 & 0,39 & 0,02 & $-46,51$ & 0,21 & 0,00 & $28,08 *$ \\
\hline 25 & PIF2B82 & 0,37 & 0,30 & $-39,49$ & 0,21 & 0,02 & $27,85^{*}$ \\
\hline 26 & PIF2C57 & 0,23 & 0,01 & 13,19 & 0,23 & 0,01 & $23,87 *$ \\
\hline 27 & PIF2D6 & 0,29 & 0,13 & $-7,82$ & 0,23 & 0,03 & $21,22 *$ \\
\hline 28 & PIF1A4 & 0,21 & 0,02 & $21,67 *$ & 0,24 & 0,05 & 17,88 \\
\hline 29 & P1F2D88 & 0,21 & 0,01 & $21,65^{*}$ & 0,24 & 0,02 & $17,34 *$ \\
\hline 30 & PIF2B68 & 0,23 & 0,01 & 13,33 & 0,43 & 0,58 & $-43,78$ \\
\hline 31 & Control & 0,27 & 0,04 & - & 0,30 & 0,05 & - \\
\hline
\end{tabular}

* significant difference with respect to the control for 7 and 21 days.

\section{Sample preparation for gas and gas-mass chromatography}

Several 50-ml glass balls were marked and weighed before adding $1000 \mu l$ of the extract. The extract was then dried in a rotatory evaporator, left to cool and weighed again to determine the dry extract weight. The initial volume of the extract samples reconstituted with ethyl acetate was calculated according to equation (1):

in which

$$
\mathrm{C}_{\mathrm{i}} \times \mathrm{V}_{\mathrm{i}}=\mathrm{C}_{\mathrm{f}} \times \mathrm{V}_{\mathrm{f}}
$$

$\mathrm{C}_{\mathrm{i}}=$ initial concentration in $\mathrm{mg}$

$\mathrm{V}_{\mathrm{i}}=$ initial volume in $\mathrm{ml}$

$\mathrm{C}_{\mathrm{f}}=$ final concentration $=50 \mathrm{mg}$

$\mathrm{V}_{\mathrm{f}}=$ final volume $=1 \mathrm{ml}$

The initial volume calculated using equation (1) was added to the dry sample. The reconstituted samples, were stored in a 1,5-ml vial for chromatographic analysis and left uncovered in the chamber until completely dry.

\section{Sample methylation and chromatographic analyses}

The dry extract samples were treated with $50 \mu$ of diazomethane. The methylated samples were placed in a double boiler at $50^{\circ} \mathrm{C}$ for 15 minutes and left uncovered for 5 minutes under an extractor to evaporate the solvent. The sample was reconstituted to a final concentration of $50 \mathrm{mg} / \mathrm{ml}$ using $1000 \mu \mathrm{l}$ of ethyl acetate. The methylated samples were analyzed in a gas chromatograph using a flame ionization detector (FID) (Agilent technologies $6890 \mathrm{~N}$; maximum temperature $325^{\circ} \mathrm{C}, 10,09$ psi, nitrogen mobile phase, $30 \mathrm{~m} \times 320 \mu \mathrm{m} \times 0,25$ 
$\mu \mathrm{m}$ column). From the GC analyzed samples, two representatives of the $O$. floccosum strain, three of the $O$. piceae, three of the $O$. piliferum and the control samples were selected for culturing for 7 and 21 days. In all cases, 50-mg samples were analyzed in a gas-mass chromatograph (Hewlett Packard 5890 Series II, HP5-MS column) with a mass detector (model 5972 series, 50-550 amu sweep range, 70-eV electro-impact ionization, $280^{\circ} \mathrm{C}$ temperature).

\section{RESULTS AND DISCUSSION}

Table 2 provides the reduction in extractives for the E. nitens wood chips biotreated with albino fungi (genus Ophiostoma.) for 7 and 21 days then extracted using an n-hexane:ethyl acetate solvent mixture. After 7 days of fungal growth, nine of the 30 strains caused a statistically significant reduction in the extractives relative to the untreated wood chips. Increasing the fungal treatment to 21 days yielded 23 out of 30 biological strains adequate for treatment and increased the extractive reduction from $30 \%$ to $70 \%$. The number of $O$. piceae strains that significantly reduced the extractives relative to the control increased from four to seven when the biotreatment was extended from 7 to 21 days. The maximum extractive reduction for both treatments was achieved with PcF1(WxPc6A)32, while the PcF2A29 strain caused the least reduction relative to the control. For the $O$. floccosum species, the number of strains capable of extractive bioreduction increased from 2 to 8 from 7 to 21 days. The strain with the maximum extractive reduction was FlF1(1 $\left.{ }^{\text {a } x A}\right) 2$ for both biotreatment durations.

For the 7-day biotreatment, $O$. piceae yielded the most significant difference relative to the control, which indicates this fungus species colonized and consumed the $E$. nitens extractives faster than the other species; however, $O$. piceae did not perform best in the 21-day biotreatment because both the $O$. floccosum- and $O$. piliferum-treated samples differed more significantly from the controls. The performance of these three species did not allow us to draw conclusions regarding their bioreduction effectiveness.

The biotreated $E$. nitens extracts analyzed via GC exhibited different degradation patterns for the pitchforming compounds. The 7-day chromatograms demonstrated no correlation between the strains with the highest extractive reduction and the lowest peak retention times. However, some strains with high extractive reductions yielded chromatograms with many retention peaks that could result from secondary metabolites. Neither of the 21-day chromatograms demonstrated a clear trend. Some strains greatly reduced the extractive concentration and presented numerous peaks similar to those of the control chromatogram, while others had increased final extractive contents and chromatograms with few peaks that differed significantly from the control chromatogram.

Extracts for the selected strains were analyzed via GC-MS (Figure 1). An analysis of the biotreatment time revealed the sharpest decline in lipophilic compounds after 7 days of biotreatment with most strains yielding an extractive reduction and most compounds, such as free sterols and fatty acids, decreasing with respect to the control. However, the free sterol content of a few fungi increased, and the breakdown resulted in variable efficiencies. The chromatographic profiles of the lipophilic extract after the 7-day biotreatment differed significantly from those of the control because most of the strains showed fewer peaks than the control.

The 21-day biotreated samples contained more free sterols and fatty acids than the control. The chromatographic profiles of the lipophilic extracts after 21 days demonstrated a limited decrease in the identified sitosterol peaks but a strong reduction in the remaining compounds relative to the control. 

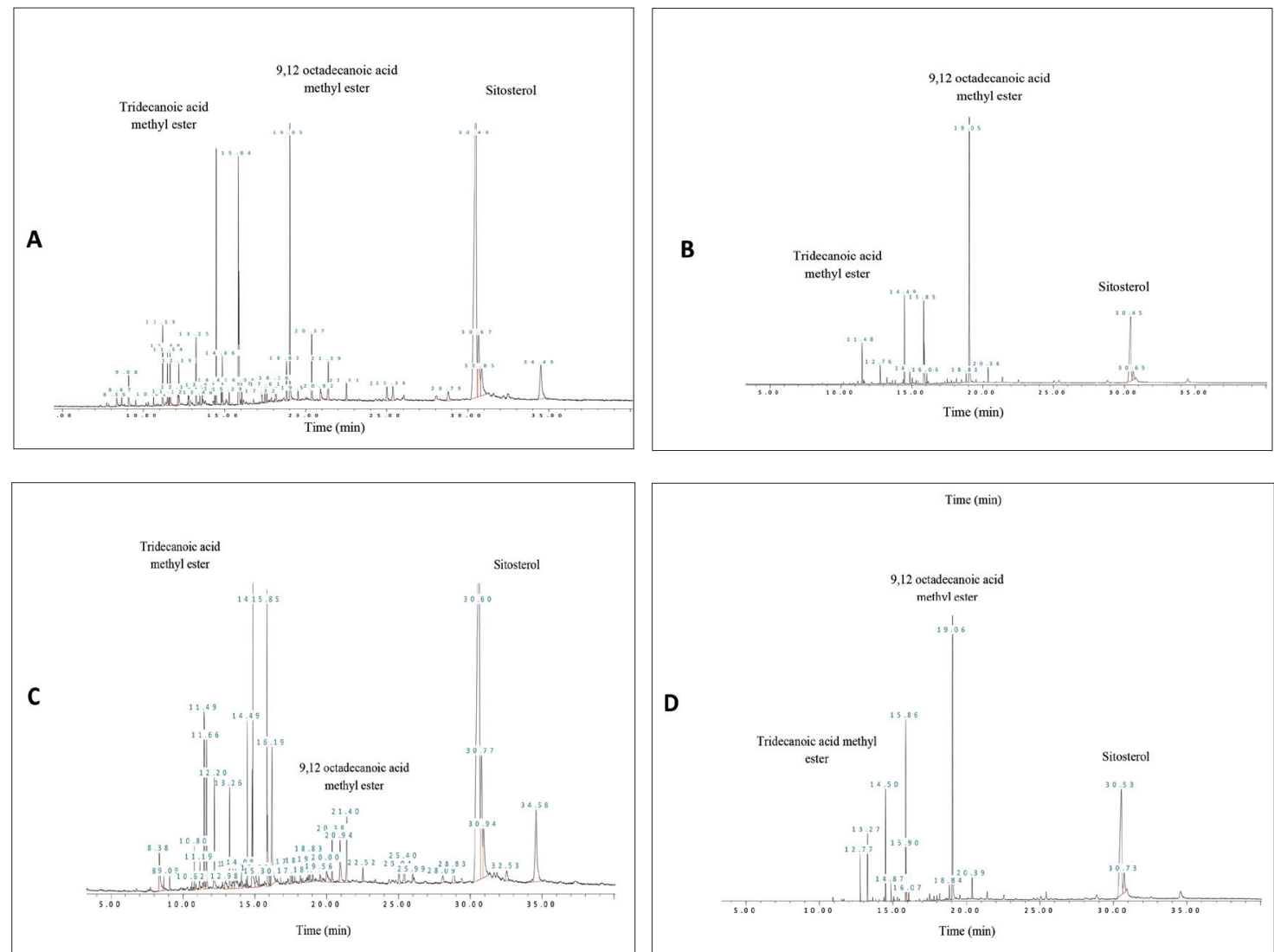

Figure 1. GC/MS chromatogram of A) E. nitens wood chip extractives without biotreatment after 7 days of exposure. (B) E. nitens extractives of chips biotreated with the O. piceae PcF2A3 strain after 7 days of exposure (C) E. nitens wood chip extractives without biotreatment after 21 days of exposure. (D)

$E$. nitens extractives of chips biotreated with the $O$. piceae PcF2A3 strain after 21 days of exposure.

The extractive contents were found to depend on the biotreatment. Some fungi decreased the free sterols while increasing the secondary metabolite content. A similar pattern was observed in the biotreated radiata pinewood (Burgos 2006). The pinewood treated with O. piliferum (Clariant Cartapip strain) exhibited reduced pitch during mechanical wood pulp processing. However, this strain was less efficient on eucalyptus because O. piliferum breaks down free sterols (Calero et al. 1999).

Tables 3 and 4 list all identified compounds. The lipid compounds detected in large quantities in E. nitens were sitosterol, tridecanoic acid methyl ester, hexadecanoic acid methyl ester, tetracosanoic acid methyl ester, heneicosanoic acid methyl ester, and 9-12-octadecadienoic acid methyl ester. Sitosterol and stigmastenol were the primary compounds in the extract. 
Table 3. Wood extractives composition determined via GC/MS as an area percentage for 7-day biotreated and control E. nitens wood chip extracts.

\begin{tabular}{|c|c|c|c|c|c|c|c|c|}
\hline Time & Compound & $\begin{array}{c}\text { Control } \\
\% \\
\end{array}$ & $\begin{array}{c}\text { F1F1A55 } \\
\%\end{array}$ & $\begin{array}{c}\text { F1F1A2 } \\
\%\end{array}$ & $\begin{array}{c}\text { PcF2A70 } \\
\%\end{array}$ & $\begin{array}{c}\text { PcF2A3 } \\
\%\end{array}$ & $\begin{array}{c}\text { PcF1A23 } \\
\%\end{array}$ & $\begin{array}{c}\text { PIF2C60 } \\
\%\end{array}$ \\
\hline 11,19 & 2,6-dimethoxybenzoquinone & 1,809 & & & & & & \\
\hline 12,19 & 4-hydroxy-3,5-dimethoxybenzaldehyde & 1,124 & & & & & & \\
\hline 13,25 & 4-hydroxy-3,5dimethoxybenzoic acid & 1,301 & & & & & 1,434 & \\
\hline 14,48 & Tridecanoic acid methyl ester & 5,403 & 6,343 & 17,336 & 5,176 & 6,848 & 6,411 & 2,516 \\
\hline 14,86 & Dibutyl phthalate & 1,057 & & & & & 2,494 & \\
\hline 15,84 & 9,12 octadecadienoic acid methyl ester & 7,654 & 7,83 & 14,067 & 6,683 & 10,906 & 7,684 & 4,194 \\
\hline 19,03 & Benzene-1,2-dicarboxylic acid & 6,242 & & & & 41,783 & & \\
\hline 20,37 & Tetracosanoic acid methyl ester & 1,985 & & & & & 1,952 & \\
\hline 30,49 & Sitosterol & 44,497 & 49,06 & 31,659 & 32,629 & 27,96 & 31,571 & 43,958 \\
\hline 30,85 & Fucosterol & 3,09 & & & 3,74 & & & \\
\hline 34,49 & Stigmast-4-en-3-one & 3,826 & & & & & 2,845 & 4,593 \\
\hline & Unidentified & 22,012 & 26,477 & 2,097 & 18,518 & 6,436 & 22,405 & 25,093 \\
\hline
\end{tabular}

Table 4. Wood extractive composition determined via GC/MS as an area percentage for 21-day biotreated and control E. nitens wood chip extracts.

\begin{tabular}{|c|c|c|c|c|c|c|c|c|}
\hline Time & Compound & $\begin{array}{c}\text { Control } \\
\%\end{array}$ & $\begin{array}{c}\text { F1F1A55 } \\
\%\end{array}$ & $\begin{array}{c}\text { F1F1A2 } \\
\%\end{array}$ & $\begin{array}{l}\text { PcF2A70 } \\
\%\end{array}$ & $\begin{array}{c}\mathrm{PcF} 2 \mathrm{~A} 3 \\
\%\end{array}$ & $\begin{array}{c}\text { PcF1A23 } \\
\%\end{array}$ & $\begin{array}{c}\text { PIF2C60 } \\
\%\end{array}$ \\
\hline 9,10 & $\begin{array}{l}\text { 3-hydroxy-4- } \\
\text { methoxybenzaldehyde }\end{array}$ & 0,234 & & & & & & \\
\hline 12,20 & $\begin{array}{l}\text { 4-hydroxy-3,5- } \\
\text { dimethoxybenzaldehyde }\end{array}$ & 2,023 & & & & & & \\
\hline 13,26 & $\begin{array}{l}\text { 4-hydroxy-3,5- } \\
\text { dimethoxybenzoic acid }\end{array}$ & 1,446 & 4,714 & 2,916 & 3,368 & 3,882 & 1,941 & 1,509 \\
\hline 14,49 & Tridecanoic acid methyl ester & 1,858 & 2,781 & & 7,75 & 5,761 & 5,249 & 3,12 \\
\hline 14,87 & Dibutyl phthalate & 6,246 & & & & & & \\
\hline 15,85 & $\begin{array}{l}9,12 \text { octadecadienoic acid } \\
\text { methyl ester }\end{array}$ & 4,652 & 6,282 & 4,429 & 11,479 & 10,171 & 10,279 & 6,704 \\
\hline 16,19 & $\begin{array}{l}\text { 9,12-octadecadienoic acid } \\
(\mathrm{Z}, \mathrm{Z})\end{array}$ & 4,372 & & & & & & \\
\hline & Unidentified & 23,64 & 15,658 & 28,243 & 19,162 & 11,787 & 27,381 & 25,743 \\
\hline
\end{tabular}

According to Gutiérrez et al. (2001), several Ascomicetes fungi included in Cartapip were inefficient at controlling Eucalyptus sp. pulp pitch and decreased the sterol ester content without affecting the free sterol quantity (sitosterols). Martínez et al. (1995) and Dorado et al. (2001) demonstrated that certain fungi of the genus Ophiostoma efficiently broke down all lipophilic components responsible for pitch deposition in Eucalyptus wood, whereas other species, including O. piliferum, decreased the sterol ester content while increasing the free sitosterol content. The reduction in sterol ester levels was related to the activity of the esterase enzyme produced by these fungi. These findings coincide with this study because the major lipids present were sitosterols.

Furthermore, Calero (2004) found that $O$. piceae sterol esterase hydrolyzed sterol esters, but increased the free sterol content, which agreed with this study in which the free sterol content of the biotreated samples increased relative to the control. This enzyme was found in several fungi studied for biocontrol over pitch (Leone and Breuil 1999, Calero et al. 1999). No sterol esters or triglycerides were detected in this study. A complete identification of the sterol esters via GC-MS was impossible (Lusby et al. 1984, Evershed et al. 1989). In recent years, attempts to characterize Eucalyptus wood extractives have indicated that triglycerides form a small fraction of E. globulus wood extractives, which primarily contain the sterol and sterol ester compounds responsible for kraft pulp pitch deposits (del Río et al. 1998, Gutiérrez et al. 1999a). 
According to Gutiérrez et al. (2001), basidiomycetes provide an alternative for reducing lipid content that is resistant to chlorine dioxide whitening and responsible for the pitch that decreased the sitosterols and sitosterol esters 60 and $70 \%$, respectively. The author suggested combining both methods to remove the extractives and lignin from the white-rot fungi-treated wood biopulp. Moreover, the fungi pretreatment significantly decreased the effluent toxicity due to the biological removal of certain extractives.

\section{CONCLUSIONS}

The strains with the best bioreduction were PcF2A14, FIF1A8 and PIF1A4 after 7 days of biotreatment and PcF2A68, Fl F1 A94 and P1 F2D8 after 21 days of biotreatment. The lipophilic extract fraction in the gas chromatographic analysis revealed that the best strains were PcF2A3 and FIF1A2 for the 7-day biotreatment and PIF1A4 for the 21-day biotreatment.

Pretreating E. nitens with 30 strains of fungi from the genus Ophiostoma for 7 and 21 days reduced the free sterol and fatty acid content of the lipophilic extracts. The primary lipophilic compounds found in the $E$. nitens extracts were free sterols, fatty acids and ketone steroids.

The best strains for industrial pretreatment to control pitch should be selected based on the optimum elimination of lipophilic extractives and the quality of the paper produced.

These results demonstrate, on the laboratory scale, a promising biological treatment for reducing and/or controlling pitch during the production of pulp and paper from E. nitens.

\section{ACKNOWLEDGEMENTS}

The authors thank the Fondo de Fomento al Desarrollo Cientifico y Tecnológico (FONDEF) for its financial support through the Fondef D04I1223 project to the Laboratorio de Productos Naturales of the Facultad de Ciencias Naturales at the Universidad de Concepción. We thank CPMC, Santa Fe pulp mill (Nacimiento, Chile) for providing the E. nitens wood chips.

\section{REFERENCES}

Blanchette, R.; Farrell, R.; Burnes, T.; Wendler, P.; Zimmerman, W.; Brush, T.; Snyder, R. 1992. Biological control of pitch in pulp and paper production by Ophiostoma. Tappi $J$ 75: 102-106.

Browning, B. 1975. The chemistry of wood. Malabar, Fla., Robert E. Krieger. vol. 2.

Burgos, R. 2006. Estudio del efecto de cepas individuales y mezclas de hongos albinos del género Ophiostoma sobre el porcentaje y composición química de los extraíbles de maderade Pinus radiata D. Don. Tesis de grado. Universidad del Bío-Bío. Chile.

Burnes, T.; Blanchette, R.; Farrell, R. 2000. Bacterial biodegradation of extractives and patterns of bordered pit membrane attack in pine wood. Applied and Environmental Microbiology 66 (12): 5201-5205.

Calero, O.; Gutiérrez, A.; del Río J.; Muñoz, M.; Plou, F.; Martínez, A.; Martínez, M. 1999. Procedimiento para el control enzimático de los depósitos de brea (pitch) formados durante la fabricación de pasta de papel utilizando una esterasa que hidroliza tanto triglicéridos como ésteres de esteroles. Spain. Patent. 
Calero, O.; Gutiérrez, A.; del Río, J.; Prieto, A.; Plou, F.; Ballesteros, A.; Martínez, A.; Martínez, M. 2004. Hydrolysis of sterol esters by an esterase from piceae: application to pitch control in pulping of Eucalyptus globules wood. Int J Biotechnology 6 (4): 367-375.

Chen, T.; Wang, Z.; Gao, Y.; Breuil, C.; Hatton, J. 1994. Wood extractives and pitch problems: analysis and partial removal by biological treatment. Appita 47: 463-466.

del Río, J.; Gutiérrez, A.; González-Vila, F.; Martín, F.; Romero, J. 1998. Characterization of organic deposits produced in the Kraft pulping of Eucalyptus globulus wood. J Chromatogaphy A 823: 457-465.

del Río, J.; Gutiérrez, A.; Martínez, M.; Martínez, A. 2001. Py-GC:MS study of Eucalyptus globulus wood treated with different fungi. Journal of Analytical and Applied Pyrolysis 58-59(1): 441-452.

Dorado, J.; van Beek, T.; Claassen, F.; Sierra-Alvarez, R. 2001. degradation of lipophilic wood extractive constituents in Pinus sylvestris by the white-rot fungi Bjerkandera sp. and Trametes versicolor. Wood Science and Technology 35 (1-2): 117-125.

Evershed, R.; Prescott, M.; Spooner, N.; Goad, L. 1989. Negative ion ammonia chemical ionization and electron impact ionization mass spectrometric analysis of steryl fatty acyl esters. Steroids 53 (3-5): 285-309.

Farrell, R.; Mulcahy, J. ; Nobbs, R. ; Rose, T.; Richardson, D.; Ram, A.; Thwaites, J.; Haryati, T.; Held, B.; McNew, D.; Blanchette, R.; Harrington, T. 2000. Research in progress: Resin degradation and brightness increase of radiate pine with fungal treatment in lab and mill trials. In: Proceedings of the International Symposium on Environmentally Friendly and Emerging Technologies for a Sustainable Pulp and Paper Industry. Eds. Su Yu-Chang, E.I.C. Wang. Taiwan Forestry Institute, Taipei, Taiwan. pp. 279-284.

Fengel, D.; Wegener, G. 1984. Wood Chemistry: Ultrastructure and Reaction. Berlin, Walter de Gruytier: $2-220$.

Fengel, D.; Wegener, G. 1989. Extractives in Wood Chemistry: Ultrastructure, Reeactions. Berlin, Walter de Gruytier: 182-226.

Fischer, K.; Akhtar, M.; Blanchette, R.; Burnes, T.; Messner, K.; Kirk, T. 1994. Reduction of resin content in wood chips during experimental biological pulping processes. Holzforschung 48: 285-290.

Fischer, K.; Akhtar, M.; Messner, K.; Blanchette, R.; Kirk, T. 1996. Pitch reduction with the white-rot fungus Ceriporiopsis subvermispora. In: Proceedings of the $6^{\text {th }}$ International Conference on Biotechnology in the Pulp and Paper Industry: Advances in Applied and Fundamental Research: 193-198.

Gutiérrez, A.; del Río J.; González-Vila, F.; Martín, F. 1999a. Chemical composition of lipophilic extractives from Eucalyptus globulus Labill wood. Holzforchung 53: 481-486.

Gutiérrez, A.; del Río J.; Martínez, M.; Martínez, A. 1999b. Fungal Degradation of Lipophilic Extractives in Eucalyptus globulus Wood. Applied and Environmental Microbiology 65 (4): 1367-1371.

Gutiérrez, A.; del Río, J.; Martínez, M.; Martínez, A. 2001. The biotechnological control pitch in paper pulp manufacturing. Trends in Biotechnology 19 (9): 340-348.

Gutiérrez, A.; del Río, J.; Ibarra, D.; Rencoret, J.; Speranza, M.; Camarero, S.; Martínez, M.; Martínez, A. 2006. Enzymatic removal of free and conjugated sterols forming pitch deposits in environmentally sound bleaching of Eucalypt paper pulp. Environmental Science and Technology 40 (10): 3416-3422. 
Held, B.; Thwaites, J.; Farrell, R.; Blanchette, R. 2003. Albino strains of Ophiostoma species for biological control of sapstain fungi. Holzforschung 57:237-242.

Herrera, P.; Navarrete, J.; Breuil, C.; Werner, E. 2008. Selección de hongos reductores de extraíbles del género Ophiostoma mediante la prueba de opacidad Tween 80. International Research Group on Wood Preservation. The international research group on wood protection IRG/WP 08-10677.

Leone, R.; Breuil, C. 1999. Biodegradation of aspen steryl esters and waxes by two filamentous fungi with or without other carbon sources. World Journal of Microbiology and Biotechnology 15 (6): 723-727.

Lusby, W.; Thompson, M.; Kochansk, J. 1984. Analysis of sterol esters by capillary gas chromatography electron impact and chemical ionization-mass spectrometry. Lipids 19(11): 888-901.

Maltha, C.; Barbosa, L.; Azevedo, M.; Colodette, J. 2011. Behavior of Eucalyptus Kraft pulp extractives components across ECF bleaching and their impact on brightness reversion. Journal of Wood Chemistry and Technology 31: 103-120.

Martínez, M.; Lenon, G.; Romero, J.; Van Der Hoeven, G.; Sierra, R.; Barrasa, J.; Keshavarz, T. 1995. Wood extracts in pulp and paper manufacture, technical and environmental implications and biological removal. [on line]. Spain. Centro de Investigaciones Biológicas y Consejo Superior de Investigaciones Científicas. <http://www.biomatnet.org/secure/Fair/S341.htm> [consulted: 24 October 2008].

Martínez-Iñigo, M.; Gutiérrez, A.; del Río, J.; Martínez, M.; Martínez,A. 2000. Time course of fungal removal of lipophilic extractives from Eucalyptus globulus wood. Journal of Biotechnology 84 (2): 119-126.

Mouyal, P. 2005. Efficient resin removal. [on line]. Atlanta: $34-35<$ www.paperage.com/issues/nov dec2005/11_2005resin.pdf> [consulted: 17 April 2007].

Pepijn, P.; Gutiérrez, A.; Rencoret, J.; Nieto, L.; Jiménez-Barbero, J.; Burnet, A.; Petit-Conil, M.; Colodette, J.L.; Martínez, Á.T. del Río, José C. 2012. Morphological characteristics and composition of lipophilic extractives and lignin in Brazilian woods from different eucalypt hybrids. Industrial Crops and Products 36: 572-583.

Rowe J.; Conner A. 1979. Extractives in eastern hardwoods. Forest Products Laboratory, Forest Service, U.S. Department of Agriculture. Madison, Wisconsin.www.flp.us. 21 (5): 23-24.

Sitholé B., Shirin S. and Ambayec B. 2010. Analysis and fate of lipophilic extractives in sulphite pulps. Journal of Wood Chemistry and Technology 30: 31-47.

Soto, C. 2001. Estudio del control de la resina de la madera en la fabricación del papel. Celulosa y Papel 19 (5): 19-36. 